\title{
Determinants of Capital Structure: Evidence From Malaysian Food and Beverage Firms
}

\author{
Mohd Faizal Basri ${ }^{1}$, Fitri Shuhaida Shoib ${ }^{2}$ \& Surianor Kamaralzaman ${ }^{2}$ \\ ${ }^{1}$ Faculty of Management and Economics, Universiti Pendidikan Sultan Idris, Tanjong Malim, Malaysia \\ ${ }^{2}$ Faculty of Business and Management, Universiti Teknologi MARA, Shah Alam, Malaysia \\ Correspondence: Mohd Faizal Basri, Faculty of Management and Economics, Universiti Pendidikan Sultan Idris, \\ Tanjong Malim, 35900 Perak, Malaysia. Tel: 60-15-4879-7112. E-mail: mfaizal.basri@fpe.upsi.edu.my
}

Received: October 10, 2019

Accepted: November 5, 2019

Online Published: December 23, 2019

doi:10.5430/rwe.v10n5p45

URL: https://doi.org/10.5430/rwe.v10n5p45

\begin{abstract}
This paper investigates the firm-specific elements, which are profitability, growth, tangible assets and liquidity in determining the capital structure of Food and Beverage (F\&B) firms in Malaysia. The research employed panel data regression model based on ordinary least square (OLS) method. The sample of research consists of eight firms listed in the food producer segment in Bursa Malaysia for the period between 2013 and 2018, with a total observation of 48 firms-years. Debt to equity was chosen as dependent variable. On the other hand, profitability, asset growth, tangibility of assets, and liquidity were selected as independent variables. The findings showed that profitability and tangibility of assets are positively related to debt to equity. Meanwhile, growth of assets and liquidity were insignificant to the dependent variable. The trade-off theory of capital structure is very much applicable to the F\&B firms in Malaysia due to the fact that profitability and tangibility of assets have significant relationship with debt.
\end{abstract}

Keywords: capital structure, food and beverage, F\&B, Malaysia, profitability, growth, tangible assets, liquidity, debt to equity

\section{Introduction}

The Malaysia Food and Beverages (F\&B) industry is diverse in nature, and show big growth with a huge export market. The F\&B industry in Malaysia has significant contributions to the Malaysia economy. In 2008, the industry generates about US\$34million in revenues with 7.6 percent annual growth rate of (British Malaysian Chamber of Commerce, 2018). Palm oil-based products are Malaysia's most essential exports in the F\&B industry, since Malaysia is one of the top two largest exporters in the world. As of 2017, the F\&B industry contributed close to 10 percent of Malaysia's exports. Importation of staples such as rice, seafood and meat are the nation's priority for domestic consumption (Italian Trade Agency, 2018; Hussain et al., 2019).

There are many variables affecting F\&B firms' capital structure including liquidity, profitability, growth, and tangible assets. Very limited researches have been conducted on the factors affecting capital structure of the F\&B especially in Malaysia, so this paper try to close the gap and create new knowledge on the factors. Furthermore, since the extent of the relationship between capital structure and firm performance cannot be generalised, there is always a constant need for a new study in different contexts to achieving a more comprehensive knowledge of the dynamics of the capital structure and the firm trade of performance (Getahun, 2014; Patnaik \& Pillai, 2017). Companies need capital to operate the company's day-to-day business, make needed investments, and expand quicker. These activities are coupled with elevated expenses where there may be adequate inner and external funding. Financial capital structure refers to how a company finances its assets through a combination of debt and equity. The choice of capital structure relies on debt and equity financing costs and advantages. That implies businesses choose the highest mixture of debt and equity that maximises the value of businesses that are called optimal capital structure. Capital structure decisions are one of the most important financial decisions faced by companies. Whether capital structures influence capital expenses and company values has been discussed for a long time. Several theories have been created since then to explain a company's assets, including the agency theory, asymmetric information, and pecking order theory (Getahun, 2014).

To provide more recent evidence on the capital structure determinants, attempts were made in this paper, to 
investigate four major factors of the capital structure of $F \& B$ firms which this paper can therefore create fresh understanding and knowledge on Malaysia's capital structure for the F\&B industry. The paper aims at examining whether profitability, growth opportunity, tangible assets and liquidity influence the capital structure of F\&B firms in Malaysia

\section{Literature Review}

\subsection{Relevant Theories}

Modigliani-Miller (M\&M) theorem which was founded by Franco Modigliani and Merton Miller in 1958 was the basis of the modern capital structure theory. The theory indicates that when the capital market is efficient or perfect, the selection of capital structure by a firm does not influence the value of the firm with the notion that there is no imposition of tax, issuance cost for capital raising activity either via debt or equity, and also zero agency cost. However, this contradicts the actual practice which ultimately attributes to a few other theories, which also discovered to challenge these findings and define the optimal capital structure for the firms from different perspectives such as the agency theory (Frangouli, 2002; Pinegar \& Wilbricht, 1989; Smith Jr. \& Warner, 1979; Jensen \& Meckling, 1976), asymmetric information (Myers \& Majluf, 1984), and pecking order theory (Barclay \& Smith, 2005; Myers \& Majluf, 1984).

\subsection{Dependent Variable}

According to Veni \& Kinfe (2015), the capital structure is the most crucial component in setting up a business. It relates to the mixture of debt and equity capital used by a company to fund its long-term operation. Furthermore, Coelho (2019) said that the capital structure is a mixture of debt, equity or other hybrid securities used to finance companies on a regular basis (Eddelani, El Idrissi and Monni, 2019).

The determinants of capital structure are the likely factors that can influence a company in choosing its capital structure. The likely factors considered include tangibility of assets, how profitable a company is growth options of the company, non-debt tax shields, the company size and among others, the volatility of corporate income (Senathip, Mujtaba \& Cavico, 2017; Anande-Kur \& Agbo, 2018; Aastha and Shazi, 2019).

\subsection{Independent Variables}

Kumar et al. (2017) found that profitability is one of the primary explanatory factors in capital structure literature. In most research, income before interest and tax are scaled by total assets or total sales. Meanwhile, Sofat \& Singh (2017) pointed out that in leveraging choices, profitability plays a significant role, Profitable firms would go for more debt financing in order to prevent wasting cash-free flows from earnings and high lucrative firms would readily acquire debt financing and also be able to acquire high debt ability. Furthermore, Vajayakumaran \& Vijayakumaran (2018) explained that the more productive companies are, the higher the use of leverage, the higher the tax shield advantages and the reduced financial distress and the debt agency costs. Profitability is measured as income separated by complete assets before interest and tax.

Growth refers to opportunity for businesses to expend and enhance their company through fresh investment utilisation. According to Nguyen (2015), the pecking order theory denotes that the expected growth and debt has a positive relationship due to the fact that companies with greater growth opportunities require higher capital to finance their developments. These companies will require more external financing, especially debt once capital need cannot be met by internal financing based on the order of preference. Likewise, Vijayakumaran \& Vijayakumaran (2018) mentioned that companies with high development potential (as assets intangible) in the future, they are likely to be at high risk, leading to higher risks of financial distress. Growth chance reflects corporate-owned intangible assets that have no collateral value. The connection between the chance for development and the amount of debt is negative. Based on Wahab et al. (2012), when companies with more chances for development need funding, they can do so by raising equity and using less debt in their future spending actions. As a result, companies with elevated growth potential are unlikely to issue debt first and equity debt is anticipated to be negatively associated with growth opportunities.

Tangible assets refer to crops, structures, machinery, and cars that generally worked to maximise sales income while trademark, goodwill, technology and patents are referred as intangible assets which are used as to support assets to reinforce the company's position. Skoogh \& Sward (2015) explained that the ratio of fixed assets over total assets a company have on its balance sheet is the measurement of tangibility. Furthermore, Iqbal et al. (2016) reported that in order to secure debt, tangible assets of a firm can be used as collateral, lowering the agency's debt expenses in the process. The price of selling securities can decrease due to the issuance of secured debt, so issuing or selling secured debt is useful to a company. Vijayakumaran \& Vijayakumaran (2018) specified that companies with more fixed 
assets can simply access secured debt as tangible assets are used as collateral for debt, and the relationship between tangible assets and debt to equity is positive. The static trade-off theory assumes that the bigger the company's fixed assets (fixed assets are collateralised for debt and thus decrease lender danger), the reduced the cost of bankruptcy and financial distress. A positive relationship between tangibility and debt to equity is anticipated in line with the explanation of both theories.

Liquidity means the capability of a firm to convert short-term assets into cash without influencing the assets' value. The theory of pecking order predicts that extremely liquid firms prefer to use internal to external funding because firms can fulfil contractual commitments on time. Therefore, it estimates a positive relationship between liquidity and debt (Veni \& Kinfe, 2015; Kurihara, 2016). Jain \& Tiwari (2018) mentioned that financing through debt requires a firm to make commitment of periodic payments in the form of interest. The firms that don't enjoy sufficient liquidity positions are prone to higher cost of financial distress as they may find it difficult to serve the debt which may turn them near bankrupt. Short-term liquidity can therefore be a significant influencing factor that determines the capital structure and is the beneficial connection between liquidity and debt to equity. Companies with low liquidity will have low leverage ratio as their financial distress costs are greater than those companies with greater liquidity. Companies with higher liquidity prefer to use the inner source of funds to finance fresh investments, thus showing the adverse liquidity-leverage connection.

alaysia for F\&B firms. The methodology outlined in this section discusses the study's variables and the statistical instruments and methods used during the course of the research. The method described the model specification, data source, variables identification, and the measurement together with the econometric model. The sample consists of eight listed F\&B firms based on market capitalisation listed on Bursa Malaysia between the year 2013 and 2018. Table 1 shows the selected firms based on the said criteria. For the calculation of dependent and independent variables, financial statements from annual reports were used.

Table 1. List of top 8 F\&B firms in Malaysia based on market capitalisation

\begin{tabular}{|c|c|c|c|c|c|c|c|c|}
\hline No. & Company & Market Cap & $\begin{array}{c}\text { Profit } \\
2013 \\
\text { (RM 000') }\end{array}$ & $\begin{array}{c}\text { Profit } \\
2014 \\
\text { (RM 000') }\end{array}$ & $\begin{array}{c}\text { Profit } \\
2015 \\
(\text { RM 000') }\end{array}$ & $\begin{array}{c}\text { Profit } \\
2016 \\
\text { (RM 000") }\end{array}$ & $\begin{array}{c}\text { Profit } \\
2017 \\
(\text { RM 000') }\end{array}$ & $\begin{array}{c}\text { Profit } \\
2018 \\
(\text { RM 000') }\end{array}$ \\
\hline 1 & NESTLE (MALAYSIA) BERHAD & $34.378 \mathrm{~b}$ & 569,413 & 511,768 & 646,684 & 571,775 & 622,612 & 670,269 \\
\hline 2 & PPB GROUP BERHAD & $26.716 \mathrm{~b}$ & 990,939 & 938,917 & 370,673 & 368,186 & 384,279 & 449,114 \\
\hline 3 & FRASER \& NEAVE HOLDINGS BHD & $12.625 b$ & 259,458 & 259,408 & 280,072 & 385,370 & 323,347 & 385,096 \\
\hline 4 & CARLSBERG BREWERY MALAYSIA BERHAD & $7.803 \mathrm{~b}$ & 186,620 & 216,921 & 220,238 & 210,665 & 232,378 & 286,757 \\
\hline 5 & HEINEKEN MALAYSIA BERHAD & $7.426 \mathrm{~b}$ & 217,604 & 198,206 & 214,193 & 427,260 & 270,058 & 282,520 \\
\hline 6 & DUTCH LADY MILK INDUSTRIES BERHAD & $4.077 \mathrm{~b}$ & 138,264 & 109,841 & 140,980 & 149,074 & 117,717 & 129,449 \\
\hline 7 & AJINOMOTO (MALAYSIA) BERHAD & $1.047 \mathrm{~b}$ & 19,404 & 28,041 & 29,733 & 40,787 & 187,462 & 56,262 \\
\hline 8 & HUP SENG INDUSTRIES BERHAD & $800 \mathrm{~m}$ & 36,745 & 38,147 & 54,731 & 49,405 & 44,447 & 42,959 \\
\hline
\end{tabular}

www.malaysiastock.biz

In this paper, the research on the F\&B firms' capital structure was interpreted. A short overview of summary statistics will be included on the dependent and independent variables. The coefficient, likelihood and other appropriate data will be displayed based on the analysis done in EViews version 10. Analysis of the information panel modelling usually used to capture sample-wide heterogeneity. Researchers use panel data to examine the capital structure determinants (De la Hoz-Rosales, Camacho and Tamayo, 2019).

Using either fixed impacts or random model effects, panel data models are typically estimated. The individual effect is a random variable in the fixed effect model, which can be correlated with the explanatory variables. The rationale behind the random effect model is that, unlike the fixed effect model, the individual specific effect is a random variable uncorrelated to the model's independent variables. The model of fixed effects is a suitable specification if we focus on a particular set of $\mathrm{N}$ firms and our inference is limited to the conduct of these firms. Also, the Hausman test can be performed to discover which of these models is the most suitable. The model of fixed effects is used in this research.

An information set consisting of both time series and cross-sectional components is referred to as a data panel or longitudinal data. In panel data models, the data set consists of $\mathrm{n}$ cross-sectional units, denoted $i=1, \ldots, \mathrm{N}$, observed 
at each of $\mathrm{T}$ time periods, $t=1, \ldots, \mathrm{T}$. In data set, the total observation is $n \times T$. Based on the following regression model, the fundamental framework for the panel data is described.

$$
\text { yit }=\alpha+' \beta x i t+\text { uit }
$$

where yit is the dependent variable, $\alpha$ is the intercept term, $\beta$ is a $\mathrm{kx} 1$ vector of parameters to be estimated on the explanatory variables, and $\mathrm{x}$ it is a $1 \mathrm{x} \mathrm{k}$ vector of observations on the explanatory variables, $t=1, \ldots, \mathrm{T} ; \mathrm{i}=1, \ldots, \mathrm{N}$.

Based on the above model, the following model was employed for the analysis:

$$
D E i t=\alpha+R O A i t+\text { GROWTHit }+ \text { TAit }+ \text { LQit }+ \text { eit }
$$

Where:

$D E i t=$ debt to equity ratio of firm $i$ at time $t$.

ROAit $=$ return on equity of firm $i$ at time $t$.

GROWTHit $=$ growth of assets of firm $i$ at time $t$.

TAit $=$ tangibility of assets of firm $i$ at time $t$.

$L Q i t=$ liquidity of firm $i$ at time $t$.

$\alpha=$ common $y$-intercept.

$\varepsilon i t=$ stochastic error term of firm $i$ at time $t$.

When leverage, with debt to equity (DE) as proxy for the dependent variable, depends on the other four independent variables i.e. return on assets (ROA) as it measures the relationship of the earning and debt of the firm. Next, growth (G) as it assesses the growth of assets of the firm in relation to the level of debt. Tangibility (TA) measured the tangibility of assets of the firm as it relates with the level of leverage. Whereas current ratio of the company and its relationship with the level of the debt is a measurement for liquidity (LQ).

\section{Results}

Table 2. Descriptive analysis

\begin{tabular}{|l|c|c|c|c|c|}
\hline & $\mathrm{DE}$ & $\mathrm{ROA}$ & $\mathrm{G}$ & $\mathrm{TA}$ & $\mathrm{LQ}$ \\
\hline Mean & 1.023781 & 0.213571 & 0.976352 & 0.308554 & 7.350567 \\
\hline Median & 0.746050 & 0.226300 & 0.956750 & 0.307450 & 1.868200 \\
\hline Maximum & 3.351400 & 0.507600 & 1.607100 & 0.588200 & 43.38320 \\
\hline Minimum & 0.001600 & 0.031600 & 0.689400 & 0.025100 & 0.649900 \\
\hline Std. Dev. & 0.942818 & 0.118434 & 0.132897 & 0.146203 & 11.97662 \\
\hline Skewness & 0.993008 & 0.089088 & 2.469063 & -0.076223 & 1.787058 \\
\hline Kurtosis & 2.927687 & 2.141620 & 12.93281 & 2.790506 & 4.664033 \\
\hline & & & & & \\
\hline Jarque-Bera & 7.898982 & 1.537127 & 246.0917 & 0.134255 & 31.08662 \\
\hline Probability & $(0.019265)$ & $(0.463679)$ & $(0.000000)^{\star \star \star}$ & $(0.935076)$ & $(0.000000)^{\star \star *}$ \\
\hline & & & & & \\
\hline Sum & 49.14150 & 10.25140 & 46.86490 & 14.81060 & 352.8272 \\
\hline Sum Sq. Dev. & 41.77860 & 0.659247 & 0.830099 & 1.004636 & 6741.656 \\
\hline & & & & & 48 \\
\hline Observations & 48 & 48 & 48 & 48 & 48 \\
\hline
\end{tabular}

Note: Figures in parentheses are the probability values. $* * * * *$ and $*$ are significant at $1 \%, 5 \%$ and $10 \%$ respectively.

Table 2 demonstrates the descriptive statistics of DE ratio for eight firms between 2013 and 2018. The total number of observations were 48 for each variable. The mean for ROA, G, TA, and LQ are 0.213, 0.976, 0.308, and 7.35 respectively. Table 2 also indicates that for the skewness in DE (0.993008) ROA 0.089088, G (2.469063) and LQ (1.787058) is skewed to the right but TA $(-0.076223)$ is skewed to the left. Meanwhile, kurtosis for DE is 2.927687 , ROA is 2.141620 , TA is 2.790506 , where the values are less than three mean platykurtic with a lower mean peak and thinner than normal distribution. On the other hand, G (12.93581) and LQ (4.664033) are more three which indicates that the data have heavier tails than a normal distribution. 
Table 3. Pearson's Correlation Coefficient Test

\begin{tabular}{crrrrr}
\hline \multicolumn{7}{c}{ DE } & \multicolumn{1}{c}{ ROA } & G & TA & LQ \\
\hline DE & 1.000000 & & & \\
\hline ROA & 0.579076 & 1.000000 & & & \\
\hline G & -0.052332 & -0.208201 & 1.000000 & & \\
\hline TA & 0.534892 & 0.198418 & -0.204829 & 1.000000 & \\
\hline LQ & -0.528422 & -0.505297 & 0.145970 & -0.594118 & 1.000000 \\
\hline
\end{tabular}

The Pearson's correlation coefficient test above was used to measure the strength between attributes or variables as presented in Table 3. Multicollinearity issue exists if the coefficient of correlation exceeds 0.80 . The outcome shows that since the variables are below 0.80 , there is no multicollinearity issue. All the variables are therefore having low correlation.

DE has positive relationships with ROA and TA but negative relationships with growth and liquidity. ROA has a very low positive relationship with TA. However, it has negative relationships with growth and liquidity. Growth has a favourable connection with liquidity but has moderate negative relationship with TA. Lastly, TA has a moderate negative relationship with liquidity.

Table 4. Levin, Lin Chin (LLC Test)

\begin{tabular}{|c|c|c|c|c|}
\hline \multicolumn{5}{|c|}{ LEVIN, LIN CHIN (LLC TEST) } \\
\hline \multicolumn{3}{|c|}{ LEVEL } & \multicolumn{2}{|c|}{$1^{\text {ST }}$ DIFFERENCE } \\
\hline VARIABLE & NO TREND & TREND & NO TREND & TREND \\
\hline Roa & $\begin{array}{c}-7.24471 \\
(0.0000)^{\cdots \cdots}\end{array}$ & $\begin{array}{c}-14.1267 \\
(0.0000)^{* \cdots}\end{array}$ & $\begin{array}{c}-17.0336 \\
(0.0000)^{* \cdots}\end{array}$ & $\begin{array}{c}-17.1802 \\
(0.0000)^{* \cdots}\end{array}$ \\
\hline Growth & $\begin{array}{c}-4.70588 \\
(0.0000)^{\cdots}\end{array}$ & $\begin{array}{c}-6.61422 \\
(0.0000)^{* \cdots}\end{array}$ & $\begin{array}{c}-6.16134 \\
(0.0000)^{\cdots}\end{array}$ & $\begin{array}{c}-7.07700 \\
(0.0000)^{\cdots}\end{array}$ \\
\hline Tangible Asset & $\begin{array}{c}-2.48669 \\
(0.0064)^{*}\end{array}$ & $\begin{array}{c}-26.1083 \\
\left.(0.0000)^{\cdots \cdots}\right)\end{array}$ & $\begin{array}{c}-21.1350 \\
(0.0000)^{* \cdots}\end{array}$ & $\begin{array}{c}-15.5428 \\
(0.0000)^{\cdots}\end{array}$ \\
\hline Liquidity & $\begin{array}{c}-9.45534 \\
(0.0000)^{\cdots}\end{array}$ & $\begin{array}{c}-11.9089 \\
(0.0000)^{\cdots \cdots}\end{array}$ & $\begin{array}{c}-15.6591 \\
(0.0000)^{\cdots}\end{array}$ & $\begin{array}{c}-22.7395 \\
(0.0000)^{\cdots}\end{array}$ \\
\hline
\end{tabular}

Note: Figures in parentheses are the probability values.***,** and $*$ are significant at $1 \%, 5 \%$ and $10 \%$ respectively.

Levin's Lin Chin test result from Table 4 above shows that information is stationary for all variables. This finding is backed by statistically significant results from the LLC test leading to the rejection of null hypothesis and there is no unit root in the variables.

Table 5. Augmented Dickey-Fuller (ADF) Test

\begin{tabular}{|c|c|c|c|c|}
\hline \multicolumn{5}{|c|}{ Fisher (ADF) } \\
\hline \multicolumn{3}{|c|}{ LEVEL } & \multicolumn{2}{|c|}{$1^{\text {ST }}$ DIFFERENCE } \\
\hline VARIABLE & NO TREND & TREND & NO TREND & TREND \\
\hline Roa & $\begin{array}{c}27.9784 \\
(0.0318)^{\star \star}\end{array}$ & $\begin{array}{c}20.4561 \\
(0.2004)\end{array}$ & $\begin{array}{c}35.6103 \\
(0.0033)^{\star \star \star \star}\end{array}$ & $\begin{array}{l}23.4757 \\
(0.1016)\end{array}$ \\
\hline Growth & $\begin{array}{l}21.0263 \\
(0.1775)\end{array}$ & $\begin{array}{l}15.6112 \\
(0.4804)\end{array}$ & $\begin{array}{c}29.6265 \\
(0.0200)^{\star \star}\end{array}$ & $\begin{array}{c}26.7640 \\
(0.0442)^{\star \star}\end{array}$ \\
\hline Tangible Asset & $\begin{array}{l}13.7157 \\
(0.6199)\end{array}$ & $\begin{array}{c}28.3613 \\
(0.0286)^{\star \star}\end{array}$ & $\begin{array}{c}36.8458 \\
(0.0022)^{\star \star \star \star}\end{array}$ & $\begin{array}{c}23.1647 \\
(0.1094)\end{array}$ \\
\hline Liquidity & $\begin{array}{c}28.2352 \\
(0.0296)^{\star \star}\end{array}$ & $\begin{array}{c}31.5725 \\
(0.0114)^{\star \star \star}\end{array}$ & $\begin{array}{c}49.6531 \\
(0.0000)^{\star \star \star \star}\end{array}$ & $\begin{array}{c}57.3174 \\
(0.0000)^{\star \star \star *}\end{array}$ \\
\hline
\end{tabular}

Note: Figures in parentheses are the probability values.***,** and * are significant at $1 \%, 5 \%$ and $10 \%$ respectively. 
The ADF test above shows that ROA \& liquidity data is stationary at Level (No Trend), tangible assets and Liquidity data at level (trend) is stationary. Meanwhile, all 1st difference (No Trend) variable is stationary and only 1 st difference (trend) growth and liquidity is stationary.

From the ADF consequence, it demonstrates that the information at 1st difference (No Trend) is stationary, so it can suppose that the entire information variable is stationary at 1st difference and can dismiss null hypothesis and that the information has no unit root.

Table 6. Phillips-Perron (PP) Test

\begin{tabular}{|c|c|c|c|c|}
\hline \multicolumn{5}{|c|}{ Fisher (Phillips Perron - PP) } \\
\hline \multicolumn{3}{|c|}{ LEVEL } & \multicolumn{2}{|c|}{$1^{\text {ST }}$ DIFFERENCE } \\
\hline VARIABLE & NO TREND & TREND & NO TREND & TREND \\
\hline Roa & $\begin{array}{c}32.2838 \\
(0.0092)^{\star \star \star \star}\end{array}$ & $\begin{array}{c}35.0103 \\
(0.0040)^{\star \star \star}\end{array}$ & $\begin{array}{c}45.3261 \\
(0.0001)^{\star \star \star}\end{array}$ & $\begin{array}{c}40.0931 \\
(0.0008)^{\star \star \star \star}\end{array}$ \\
\hline Growth & $\begin{array}{l}26.5822 \\
(0.0464)^{\star \star}\end{array}$ & $\begin{array}{l}27.6975 \\
(0.0344)^{\star \star}\end{array}$ & $\begin{array}{c}34.3490 \\
(0.0049)^{\star \star \star \star}\end{array}$ & $\begin{array}{l}44.1356 \\
(0.0002)\end{array}$ \\
\hline $\begin{array}{c}\text { Tangible } \\
\text { Asset }\end{array}$ & $\begin{array}{l}13.7719 \\
(0.6157)\end{array}$ & $\begin{array}{c}40.7528 \\
(0.0006)^{\star \star \star \star}\end{array}$ & $\begin{array}{c}42.9861 \\
(0.0003)^{\star \star \star}\end{array}$ & $\begin{array}{c}43.3768 \\
(0.0002)^{\star \star \star \star}\end{array}$ \\
\hline Liquidity & $\begin{array}{c}40.9287 \\
(0.0006)^{\star \star \star}\end{array}$ & $\begin{array}{c}52.5979 \\
(0.0000)^{\star \star \star}\end{array}$ & $\begin{array}{c}54.6804 \\
(0.0000)^{\star \star \star}\end{array}$ & $\begin{array}{c}82.0537 \\
(0.0000)^{\star \star \star}\end{array}$ \\
\hline
\end{tabular}

Note: Figures in parentheses are the probability values. ${ }^{* *}, * *$ and $*$ are significant at $1 \%, 5 \%$ and $10 \%$ respectively.

The PP test outcome as per Table 6 shows that information is stationary for all factors except for concrete assets at Level (no trend) is non-stationary but stationary after the first difference. All variables are stationary at the 1st difference and the outcome of the LLC test can dismiss the null hypothesis and the information has no unit root.

Table 7. Regression Analysis

\begin{tabular}{|c|c|c|c|c|}
\hline $\begin{array}{l}\text { Dependent Variable: } \\
\text { Method: Panel Least } \\
\text { Date: } 05 / 22 / 19 \text { Time } \\
\text { Sample: } 20132018 \\
\text { Periods included: } 6 \\
\text { Cross-sections includ } \\
\text { Total panel (balanced }\end{array}$ & ervations: 48 & & & \\
\hline Variable & Coefficient & Std. Error & $\mathrm{t}$-Statistic & Prob. \\
\hline C & -1.748448 & 0.938667 & -1.862693 & 0.0693 \\
\hline ROA & 4.038470 & 0.980824 & 4.117425 & $0.0002^{* \star *}$ \\
\hline G & 1.058154 & 0.762652 & 1.387466 & 0.1724 \\
\hline TA & 2.892348 & 0.851172 & 3.398079 & 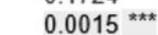 \\
\hline LQ & -0.002156 & 0.011642 & -0.185176 & 0.8540 \\
\hline R-squared & 0.540338 & Mean depend & nt var & 1.023781 \\
\hline Adjusted R-squared & 0.497579 & S.D. depende & var & 0.942818 \\
\hline S.E. of regression & 0.668286 & Akaike info cri & erion & 2.130130 \\
\hline Sum squared resid & 19.20404 & Schwarz criter & & 2.325047 \\
\hline Log likelihood & -46.12312 & Hannan-Quinr & criter. & 2.203789 \\
\hline F-statistic & 12.63674 & Durbin-Watso & & 0.422789 \\
\hline Prob(F-statistic) & 0.000001 & & & \\
\hline
\end{tabular}

Note: Figures in parentheses are the probability values. $* * *, * *$ and $*$ are significant at $1 \%, 5 \%$ and $10 \%$ respectively.

Based on Table 7, the determination coefficient or the R-squared for F\&B firms in Malaysia is 0.540338 which indicates that 54.03 percent change in equity debt can be explained by modifications in asset returns, grow, tangible assets and liquidity. Meanwhile, the other 45.7 percent of changes cannot be clarified by the current set of independent variables because of the other factors not included in the regression equation.

Meanwhile, adjusted R-Squared is 0.497579 that has been adjusted for the number of independent variables in the 
model. Probability F-Statistics is 0.000001 , which is a substantial amount of less than 1 percent, there is enough proof to conclude that dependent variables can be explained by at least one of the independent variables.

The first coefficient value, 4.03847 (ROA) indicates that for one Malaysian Ringgit (MYR) increased in ROA, the leverage will increase by MYR4.03. Additionally, the P-value of profitability (ROA) is 0.0002 which is less than $1 \%$ significant level. Profitability (ROA) and Debt to Equity (DE) shows a significant positive relationship, this result is supported by Jaafar et al. (2017) and Sofat \& Singh (2017).

As for assets growth $(\mathrm{G})$, the p-value is 0.1724 which more than $10 \%$ significant level. Growth $(\mathrm{G})$ and Debt to Equity (DE) shows no significant relationship and this result supported by Vijayakumaran \& Vijayakumaran, (2018).

Meanwhile, 2.892348 (TA) indicates that for every one MYR increased in TA, there would be an increase of MYR2.89 in leverage. The p-value of TA is 0.0015 which is less than $1 \%$ significant level. TA and DE shows significant positive relationship which was supported by Jaafar et al. (2017) and Vijayakumaran \& Vijayakumaran (2018).

Lastly, as for LQ, the p-value is 0.8540 , which is more than $10 \%$ significant level. This indicates that liquidity has no relationship with DE for F\&B firms is Malaysia. The result is consistent with Jain and Tiwari (2018) and Suhaila and Wan Mahmood (2008); Koirala \& Koirala (2016).

\section{Discussion}

This paper has established that the DE ratio as the dependent variable, and ROA, growth, tangibility and liquidity as the independent variables to determine the capital structure for the F\&B firms in Malaysia.

Firstly, the results from the findings exhibited that ROA and DE ratio has a positive significant relationship for the Malaysian F\&B firms. This demonstrated that leverage level of a firm can be affected from the fluctuations of profitability. Debt also considered as the choice of financing for the money-making firms. This suggests that trade off theory is applicable to Malaysian F\&B firms.

Next, asset growth and DE ratio showed no relationship between the two variables. This is consistent with theory of optimal capital structure where capital structure is irrelevant to growth of the assets of a company.

Thirdly, the study found that TA and DE ratio has a positive significant relationship for the F\&B firms in Malaysia. The increment of the level of leverage with tangibility of assets are due to the need of debt financing by the firms so that the firms can improve the total assets. Furthermore, firms that have the intention to acquire high-priced assets would find that debt financing is the ideal option.

Finally, the relationship between liquidity and DE ratio was found insignificant. The irrelevant relationship between liquidity and leverage is consistent with the pecking order theory. In procuring new assets, internal funds will be the option for firms with greater liquidity. Several empirical studies found that pecking order theory fit their findings. Moving forward, future researches might consider exploring additional variables that can determine the capital structure of F\&B firms in Malaysia to complement the findings of this study.

\section{References}

Anande-Kur, F., \& Agbo, A. (2018). Determinants of capital structure in the Nigerian manufacturing sector. AE-Funai Journal of Accounting, Business and Finance, 3(1), 178-185.

Aastha, B., \& Shazi, S.J. (2019). Corporate social responsibility practices in small and medium enterprises. Polish Journal of Management Studies, 19(1), 9-20.

Barclay, M.J., \& Smith, C.W. (2005). The capital structure puzzle: The evidence revisited. Journal of Applied Corporate Finance, 17(1), 8-17.

British Malaysian Chamber of Commerce. (2018). Malaysian Industry Report 2018/2019: Food \& Beverage. Kuala Lumpur, Malaysia.

Coelho, M.D.S. (2019). The determinants of capital structure in Latin America: new evidence using firm and country variables (Doctoral dissertation).

De la Hoz-Rosales, B., Camacho, J., \& Tamayo, I. (2019). Effects of innovative entrepreneurship and the information society on social progress: an international analysis. Entrepreneurship and Sustainability Issues, 7(2), 782-813. https://doi.org/10.9770/jesi.2019.7.2(1)

Eddelani, O., El Idrissi, N.E., \& Monni, S. (2019). Territorialized forms of production in Morocco: provisional assessment for an own model in gestation. Insights into Regional Development, 1(1), 6-8. https://doi.org/10.9770/ird.2019.1.1(1) 
Frangouli, Z. (2002). Capital structure, product differentiation and monopoly power: A panel method approach. Managerial Finance, 28(5), 59-65.

Getahun, M. (2014). Determinants of capital structure and its impact on the performance of Ethiopian insurance industry (Doctoral dissertation, Jimma University).

Hussain, H.I., Herman, Ghani, E.K., \& Razimi, M.S.A. (2019). Systematic Risk and Determinants of Cost of Capital: An Empirical Analysis of Selected Case Studies. Journal of Security and Sustainability Issues, 9(1), 295-307.

Iqbal, A., Ahsan, T., \& Zhang, X. (2016). Credit supply and corporate capital structure: evidence from Pakistan. South Asian Journal of Global Business Research, 5(2), 250-267.

Italian Trade Agency. (2018). Food and Beverages Market Report in Malaysia. Rome, Italy.

Jaafar, M.N., Muhamat, A.A., Ahmad, I., \& Alwi, S.F.S. (2017). Determinants of capital structure: Empirical evidence from Shariah compliant plantation firms in Malaysia. Journal of Emerging Economies and Islamic Research, 5(4), 1-9.

Jain, H.C., \& Tiwari, H.N. (2018). Determinants of capital structure in Indian pharmaceutical industry. International Journal for Research in Engineering Application \& Management, 4(7), 337-345.

Jensen, M.C., \& Meckling, W.H. (1976). Theory of the firm: Managerial behavior, agency costs and ownership structure. Journal of Financial Economics, 3(4), 305-360.

Koirala, N.P., \& Koirala, D.P. (2016). Poverty and Inequality across the Nations: How Can Governments be Effective in Coping?. Economy, 3(1), 24-30.

Kumar, S., Colombage, S., \& Rao, P. (2017). Research on capital structure determinants: a review and future directions. International Journal of Managerial Finance, 13(2), 106-132.

Kurihara, Y. (2016). Term Structure of Interest Rates under Zero or Low Bound: The Recent Japanese Case. Economy, 3(1), 19-23.

Modigliani, F., \& Miller, M. (1958). The cost of capital, corporate finance and the theory of investment. The American Economic Review, XLVII(3), 261-297.

Myers, S.C., \& Majluf, N.S. (1984). Corporate financing and investment decisions when firms have information that investors do not have. Journal of Financial Economics, 13(2), 187-221.

Nguyen, D. (2013). Determinants of Capital Structure in Vietnam. Available at SSRN 2481417.

Patnaik, D., \& Pillai, A. (2017). Responsiveness of the Indian Tax System: A Time Series Analysis from 1990 to 2010. Economy, 4(1), 1-6.

Pinegar, J.M., \& Wilbricht, L. (1989). What managers think of capital structure theory: a survey. Financial Management, 82-91.

Senathip, T., Mujtaba, B.G., \& Cavico, F.J. (2017). Policy-Making Considerations for Ethical and Sustainable Economic Development. Economy, 4(1), 7-14.

Skoogh, J., \& Swärd, P. (2015). The Impact of Tangible Assets on Capital Structure-An analysis of Swedish listed companies. (Dissertation).

Smith Jr, C.W., \& Warner, J.B. (1979). On financial contracting: An analysis of bond covenants. Journal of Financial Economics, 7(2), 117-161.

Sofat, R., \& Singh, S. (2017). Determinants of capital structure: an empirical study of manufacturing firms in India. International Journal of Law and Management, 59(6), 1029-1045.

Suhaila, M.K., \& Wan Mahmood, W.M. (2008). Capital Structure and Firm Characteristics: Some Evidence from Malaysian Companies. Munich Personal RePEc Archive (MPRA), 1-16.

Umaru, R.I., \& Ombugus, D.A. (2017). Determinants of job satisfaction of Colleges of Education Lecturers: A study of Nasarawa State College of Education, Akwanga. Asian Business Research Journal, 2, 8-13.

Veni, P., \& Kinfe, S. (2015). Determinants of capital structure in Ethiopian private manufacturing sector. International Journal of Academic Research and Development, 3(2), 1231-1240.

Vijayakumaran, S., \& Vijayakumaran, R. (2018). The determinants of capital structure decisions: Evidence from Chinese listed companies. Asian Journal of Finance \& Accounting, 10(2), 63-81.

Wahab, R.A., Amin, M.S.M., \& Yusop, K. (2012). Determinants of capital structure of Malaysian property developers. Middle-East Journal of Scientific Research, 11(8), 1013-1021. 